\title{
Literasi Matematika Dalam Kurikulum 2013
}

\author{
Syahlan \\ Dosen FKIP UISU \\ syahlan@fkip.uisu.ac.id
}

\begin{abstract}
ABSTRAK
Keikutsertaan Indonesia di dalam studi International seperti Trends in International Mathematics and Science Study (TIMSS) dan Program for International Student Assessment (PISA) sejak tahun 1999 menunjukkan bahwa capaian anak-anak Indonesia tidak menggembirakan dalam beberapa kali laporan yang dikeluarkan TIMSS dan PISA, menuntut adanya perubahan besar dalam tujuan pendidikan Indonesia.Kurikulum 2013 yang mengusung paradigma belajar abad 21 memiliki tujuan agar siswa memiliki kompetensi sikap, keterampilan, dan pengetahuan yang lebih baik, yang pada akhirnya akan mewujudkan terciptanya masyarakat belajar (learning society), dimana setiap anggota masyarakat berhak mendapatkan pendidikan (education for all) dan menjadi pembelajar seumur hidup (longlive education). Dengan literasi matematika, siswa akan mampu melakukan, memahami, dan menerapkan matematika, tidak hanya di dalam kelas tetapi juga dalam kehidupan sehari-hari, selain itu siswa diajak untuk berpikir kritis terhadap instruksi yang diberikan. Kesempatan untuk mengembangkan literasi matematika dapat sekaligus memperdalam pengetahuan mereka terhadap matematika, pemahaman konseptual dan keterampilan sehingga tujuan pendidikan nasional akan tercapai. Disarankan untuk mengkaji secara mendalam kurikulum tahun 2013 untuk lebih memahaminya dan dapat menerapkannya secara efisien dan efektif. Mempertimbangkan upaya-upaya yang tepat sehingga kompetensi inti yang telah ditetapkan berdasarkan standar kompetensi lulusan (SKL) dapat tercapai. Menerapkan dan mengembangkan kemampuan peserta didik dengan menggunakan literasi matematika sehingga siswa dapat lebih menikmati matematika, bukan sebagai suatu momok yang harus dihindari.
\end{abstract}

Kata kunci: literasi matematika, kurikulum.

\section{PENDAHULUAN}

Keikutsertaan Indonesia di dalam studi International Trends in International Mathematics and Science Study (TIMSS) dan Program for International Student Assessment (PISA) sejak tahun 1999 juga menunjukkan bahwa capaian anak-anak Indonesia tidak menggembirakan dalam beberapa kali laporan yang dikeluarkan TIMSS dan PISA. Capaian anak-anak Indonesia ini disebabkan karena tidak sesuainya antara materi uji dengan kurikulum yang berlaku di Indonesia. Selain itu, arus globalisasi yang menggeser pola hidup masyarakat dari agraris dan perniagaan tradisional menjadi masyarakat industri dan perdagangan modern seperti dapat terlihat di World Trade Organization (WTO), Association of Southeast Asian Nations (ASEAN) Community, AsiaPacific Economic Cooperation (APEC), dan ASEAN Free Trade Area (AFTA) menuntut adanya perubahan besar dalam tujuan pendidikan Indonesia. Untuk mencapai tujuan pendidikan tersebut, Indonesia membuat suatu kurikulum baru yang mengatur seperangkat rencana dan pengaturan mengenai tujuan, isi, dan bahan pelajaran serta cara yang digunakan sebagai pedoman penyelenggaraan kegiatan pembelajaran untuk mencapai tujuan pendidikan tertentu.

Pedoman penyelenggaraan kegiatan pembelajaran menjadi salah satu aspek yang penting dalam implementasi kurikulum tahun 2013. Ada dua aspek yang telah diatur sebagai pedoman penyelenggaraan kegiatan pembelajaran, yaitu standar proses dan standar penilaian. Untuk standar proses, ditetapkan prinsip dan karakteristik pembelajaran yang dapat digunakan sedangkan untuk 
standar penilaian, ditetapkan prinsip dan pendekatan penilaian; ruang lingkup, teknik dan instrumen penilaian; mekanisme dan prosedur penilaian; dan pelaksanaan dan pelaporan penilaian.

Kedua pedoman tersebut tidak mengupas secara jelas tentang metode yang tepat dan sesuai dalam melaksanakan proses pembelajaran, khususnya pada pembelajaran matematika. Berbagai pola pengajaran yang selama ini diterapkan masih dirasa kurang dapat membantu siswa untuk mencapai Standar Kompetensi Lulusan (SKL) yang ditetapkan. Standar Kompetensi Lulusan (SKL) yang ditetapkan mengacu pada PISA menekankan pada kemampuan dan pengetahuan matematika yang diluar dari matematika yang telah didefinisikan dan tidak terbatas pada kurikulum sekolah.

Untuk mengembangkan pengetahuan dan keterampilan peserta didik dalam bidang matematika diperlukan suatu kemampuan untuk mengidentifikasi, memahami, mengolah informasi untuk selanjutnya membuat keputusan yang tepat dalam menyelesaikan masalah. Kemampuan yang dimaksud adalah literasi matematika. Literasi matematika di Indonesia kurang dimanfaatkan sebagai salah satu alternatif dalam proses pembelajaran matematika, oleh karena itu dalam makalah ini akan diuraikan betapa pentingnya literasi matematika dalam pendidikan matematika.

Adapun tujuan penulisan makalah ini adalah untuk:

1. Mengetahui tentang kurikulum tahun 2013.

2. Mengetahui hal-hal yang terkait dalam kurikulum matematika tahun 2013.

3. Mengetahui akan pentingnya literasi dalam implementasi kurikulum matematika tahun 2013.

\section{PEMBAHASAN}

\section{A. Kurikulum Tahun 2013}

Kurikulum tahun 2013 merupakan tinjauan terhadap kurikulum sebelumnya yang tujuannya adalah untuk memperbaiki Standar Kompetensi dan Kompetensi Dasar yang tidak relevan bagi siswa, perbaikan terhadap sistem pelatihan guru, serta penggunaan alat dan teknologi dalam implementasi pembelajaran matematika di sekolah. Kurikulum 2013 mulai dikembangkan sejak tahun 2010 yang dmulai dengan melakukan kajian dokumen kurikulum, penyusunan panduan pendidikan karakter, dan piloting pendidikan karakter di satuan pendidikan. Secara rinci program pengembangan kurikulum dapat dilihat pada digram berikut.

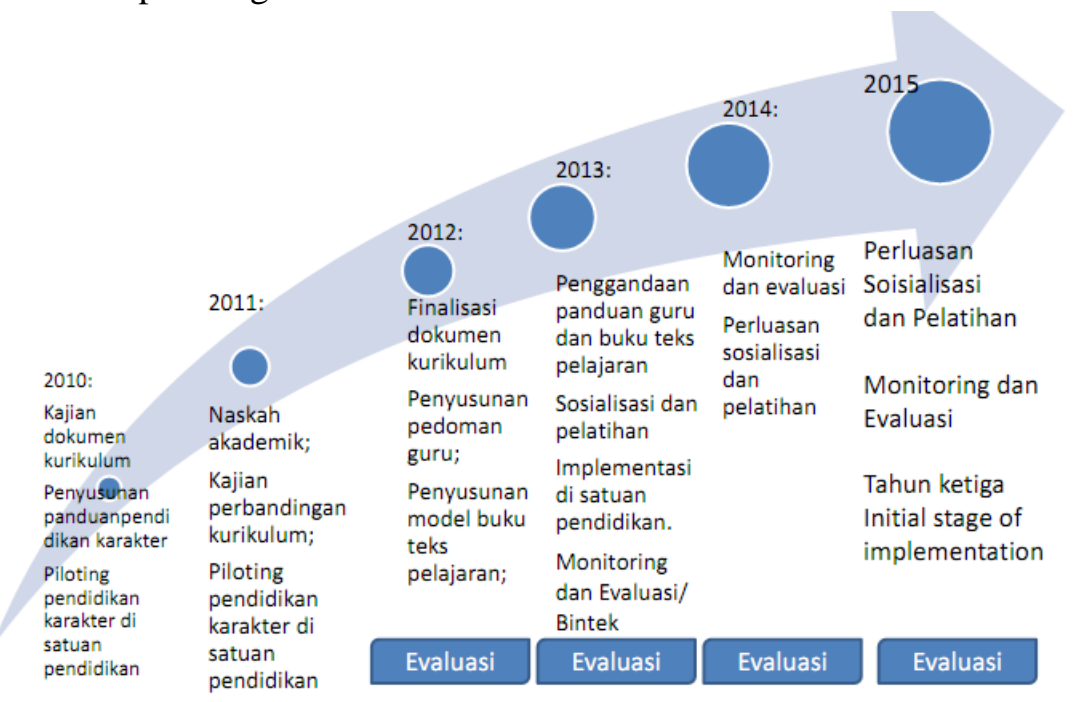

Gambar 1. Program Pengembangan Kurikulum (Hamid Hasan; 2013, 5) 
Kurikulum 2013 yang mengusung paradigma belajar abad 21, perlu menerapkan pendekatan kontekstual. Pendekatan kontekstual diharapkan dapat membantu siswa untuk melakukan observasi, bertanya, bernalar, dan mengkomunikasikan apa yang diperoleh atau diketahuinya yang merupakan tujuan pendidikan nasional. Melalui pendekatan ini diharapkan siswa memiliki kompetensi sikap, keterampilan, dan pengetahuan yang lebih baik, yang pada akhirnya akan mewujudkan terciptanya masyarakat belajar (learning society), dimana setiap anggota masyarakat berhak mendapatkan pendidikan (education for all) dan menjadi pembelajar seumur hidup (longlive education). Hal ini sesuai dengan pendapat BSNP dalam artikelnya yang berjudul "Paradigma Pendidikan Nasional Abad XXI bagian VII. BSNP (2013) menjelaskan bahwa:

"Paradigma pendidikan yang terlalu terfokus pada kepentingan pragmatis, teaching mind melalui drill \& skill sekarang perlu diseimbangkan dengan tujuan ideal touching heart melalui ethics \& esthetics. Mesti disegarkan kembali bahwa pendidikan merupakan kekuatan moral dan intelektual yang berjalan seimbang, tidak boleh timpang. Selama ini Nampak bahwa pendidikan di Indonesia terlalu menekankan aspek intelektual, kurang memperhatikan aspek moralitas. Lebih banyak berkutat tentang pemenuhan kepentingan pasar dan industri ketimbang pengembangan karakter dan kearifan."

Permendikbud No. 65 tahun 2013 menguraikan bahwa prinsip-prinsip pembelajaran yang digunakan pada kurikulum 2013 adalah bahwa siapa saja adalah guru, siapa saja adalah siswa, dan dimana saja adalah kelas. Pendekatan yang digunakan merupakan pendekatan ilmiah yang mengacu pada keterampilan aplikatif yang dapat menyeimbangkan antara keterampilan fisikal (hardskill) dan keterampilan mental (softskill). Peserta didik diajak untuk mencari tahu, bukan diberi tahu, yang memanfaatkan beraneka sumber belajar sehingga pembelajaran yang terjadi tidak hanya di kelas tetapi juga dapat terjadi di rumah, maupun di masyarakat.

\section{B. Kurikulum Matematika Tahun 2013}

Hasil penelitian yang dilakukan oleh PISA (Programme for International Student Assessment) dan TIMSS (Trend in International Mathematics and Science Study) disimpulkan bahwa hampir semua siswa Indonesia hanya menguasai pelajaran sampai level 3 saja, sementara Negara lain banyak yang sampai level 4, 5 dan 6. Untuk mengejar ketertinggalan pendidikan di Indonesia yang mengacu pada PISA dan TIMSS serta tuntutan zaman yang terus berkembang, maka perlu adanya perbaikan kurikulum, khususnya pada pendidikan matematika. Berdasarkan hal tersebut, maka dilakukanlah uji perbandingan antara kurikulum yang berlaku di Indonesia dengan materi dari PISA dan TIMSS.

Uji perbandingan yang dilakukan tersebut, maka perlu dilakukan tiga hal sebagai berikut: a) melakukan evaluasi ulang ruang lingkup materi, b) melakukan evaluasi ulang kedalaman materi sesuai dengan tuntutan perbandingan internasional, yaitu sampai dengan reasoning, c) menyusun kompetensi dasar yang sesuai dengan materi yang dibutuhkan.

Adapun untuk evaluasi terhadap ruang lingkup materi kurikulum matematika dilakukan dengan cara: a) meniadakan materi yang tidak esensial atau tidak relevan bagi siswa, b) mempertahankan materi yang sesuai dengan kebutuhan siswa, c) menambah materi yang dianggap penting dalam perbandingan internasional. Secara garis besar, perubahan materi isi matematika dapat dilihat pada tabel berikut. 
Tabel 1. Perubahan Materi Isi Matematika

\begin{tabular}{|c|c|c|}
\hline No & Kurikulum Lama & Kurikulum Baru \\
\hline 1 & $\begin{array}{l}\text { Langsung masuk ke materi } \\
\text { abstrak }\end{array}$ & $\begin{array}{l}\text { Mulai dari pengamatan permasalahan konkret, } \\
\text { kemudian ke semi konkret, dan akhirnya } \\
\text { abstraksi permasalahan }\end{array}$ \\
\hline 2 & $\begin{array}{l}\text { Banyak rumus yang harus } \\
\text { dihafal untuk menyelesaikan } \\
\text { permasalahan (hanya bisa } \\
\text { menggunakan) }\end{array}$ & $\begin{array}{l}\text { Rumus diturunkan oleh siswa dan } \\
\text { permasalahan yang diajukan harus dapat } \\
\text { dikerjakan siswa hanya dengan rumus-rumus } \\
\text { dan pengertian dasar (tidak hanya bisa } \\
\text { menggunakan tetapi juga memahami asal- } \\
\text { usulnya) }\end{array}$ \\
\hline 3 & $\begin{array}{l}\text { Permasalahan matematika selalu } \\
\text { diasosiasikan dengan [direduksi } \\
\text { menjadi] angka }\end{array}$ & $\begin{array}{l}\text { Perimbangan antara matematika dengan angka } \\
\text { dan tanpa angka [gambar, grafik, pola, dsb] }\end{array}$ \\
\hline 4 & $\begin{array}{l}\text { Tidak membiasakan siswa untuk } \\
\text { berfikir kritis [hanya mekanistis] }\end{array}$ & $\begin{array}{l}\text { Dirancang supaya siswa harus berfikir kritis } \\
\text { untuk menyelesaikan permasalahan yang } \\
\text { diajukan }\end{array}$ \\
\hline 5 & $\begin{array}{l}\text { Metode penyelesaian masalah } \\
\text { yang tidak terstruktur }\end{array}$ & Membiasakan siswa berfikir algoritmis \\
\hline 6 & $\begin{array}{l}\text { Data dan statistik dikenalkan di } \\
\text { kelas IX saja }\end{array}$ & $\begin{array}{l}\text { Memperluas materi mencakup peluang, } \\
\text { pengolahan data, dan statistik sejak kelas VII } \\
\text { serta materi lain sesuai dengan standar } \\
\text { internasional }\end{array}$ \\
\hline 7 & Matematika adalah eksak & $\begin{array}{l}\text { Mengenalkan konsep pendekatan dan } \\
\text { perkiraan }\end{array}$ \\
\hline
\end{tabular}

Setelah menetapkan materi isi pembelajaran matematika, selanjutnya ditetapkan Standar Kompetensi Lulusan (SKL) yang berlaku untuk setiap jenjang pendidikan. Secara umum ada tiga aspek yang menjadi kompetensi lulusan yaitu sikap, keterampilan dan pengetahuan. Secara terperinci, standar kompetensi lulusan dalam presentasinya dapat dilihat pada tabel berikut ini.

Tabel 2. Standar Kompetensi Lulusan (SKL)

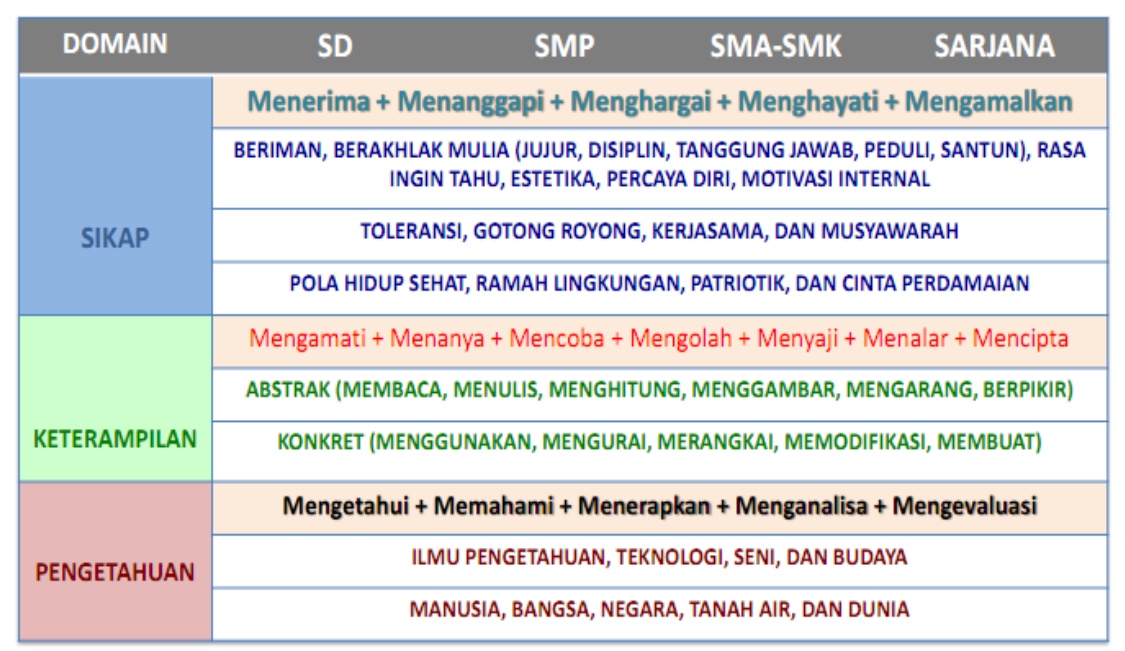


Berdasarkan Standar Kompetensi Lulusan yang ditetapkan, dirumuskan empat Kompetensi Inti yaitu:

1. Kompetensi Inti untuk Sikap Spiritual

Untuk sikap spiritual, kompetensi yang ditetapkan berkaitan dengan aspek keagamaan yaitu "menghayati dan mengamalkan ajaran agama yang dianutnya".

2. Kompetensi Inti untuk Sikap Sosial

Menghayati dan mengamalkan perilaku jujur, disiplin, tanggungjawab, peduli (gotong royong, kerjasama, toleran, damai), santun, responsif dan pro-aktif dan menunjukkan sikap sebagai bagian dari solusi atas berbagai permasalahan dalam berinteraksi secara efektif dengan lingkungan sosial dan alam serta dalam menempatkan diri sebagai cerminan bangsa dalam pergaulan dunia merupakan kompetensi inti untuk sikap social.

3. Kompetensi Inti Pengetahuan

Dalam kurikulum matematika, kompetensi inti pengetahuannya adalah memahami, menerapkan, menganalisis dan mengevaluasi pengetahuan faktual, konseptual, prosedural, dan metakognitif berdasarkan rasa ingin tahunya tentang ilmu pengetahuan, teknologi, seni, budaya, dan humaniora dengan wawasan kemanusiaan, kebangsaan, kenegaraan, dan peradaban terkait penyebab fenomena dan kejadian, serta menerapkan pengetahuan prosedural pada bidang kajian yang spesifik sesuai dengan bakat dan minatnya untuk memecahkan masalah.

4. Kompetensi Inti Keterampilan

Dalam aspek keterampilan, kompetensi intinya adalah mengolah, menalar, menyaji, dan mencipta dalam ranah konkret dan ranah abstrak terkait dengan pengembangan dari yang dipelajarinya di sekolah secara mandiri serta bertindak secara efektif dan kreatif, dan mampu menggunakan metoda sesuai kaidah keilmuan.

\section{Pentingnya Literasi dalam Implementasi Kurikulum Matematika Tahun 2013}

Materi isi pelajaran matematika yang telah dikembangkan dalam kurikulum 2013 menganggap penting perimbangan antara matematika dengan angka dan tanpa angka (gambar, grafik, maupun pola). Untuk mampu memahami matematika tanpa angka, dibutuhkan kemampuan literasi yang baik. Literasi merupakan kemampuan siswa dalam membaca suatu informasi, mulai dari mengidentifikasi, memahami masalah dan membuat suatu keputusan untuk menetapkan cara penyelesaiannya, seperti yang dinyatakan oleh OECD, bahwa:

Mathematical literasi is an individual's capacity to identify, and understand, the role that mathematics plays in the world, to make well-founded judgments and to use and engage with mathematics in ways that meet the needs of that individual's life as a constructive, concerned, and reflective citizen. (OECD, 2003).

Literasi meliputi seperangkat kemampuan yang kompleks untuk memahami dan menggunakan sistem simbol untuk pengembangan pribadi dan masyarakat. Dalam masyarakat teknologi, konsep keaksaraan sedang berkembang untuk menyertakan media dan teks elektronik, selain abjad dan sistem nomor. Kemampuan ini bervariasi dalam konteks sosial dan budaya yang berbeda sesuai dengan kebutuhan, permintaan dan pendidikan.

Tujuan utama literasi masih merupakan pembelajaran seumur hidup (livelong education), proses intelektual untuk mendapatkan makna dari interpretasi kritis terhadap teks tertulis atau dicetak. Kunci untuk semua literasi adalah membaca, perkembangan keterampilan yang diawali dengan 
kemampuan untuk memahami kata-kata yang diucapkan dan menguraikan sandi dari kata-kata tertulis, hingga sampai kepada pemahaman mendalam tentang teks. Membaca melibatkan berbagai dasar-dasar bahasa yang kompleks yang diperlukan untuk membaca kefasihan dan pemahaman. Setelah keterampilan ini diperoleh pembaca dapat mencapai melek bahasa penuh, yang mencakup kemampuan untuk mendekati bahan cetak dengan analisis kritis, kesimpulan dan sintesis, untuk menulis dengan akurasi dan koherensi, dan menggunakan informasi dan wawasan dari teks sebagai dasar untuk keputusan dan berpikir kreatif.

Literasi Matematika adalah pengetahuan matematika, metode, dan proses yang diterapkan dalam berbagai konteks dalam wawasan dan cara reflektif. Menurut de Lange (Ronda, 2011), literasi matematika adalah keaksaraan menyeluruh yang meliputi berhitung, kesadaran terhadap literasi kuantitatif dan literasi spasial, seperti yang ditunjukkan pada skema berikut ini.

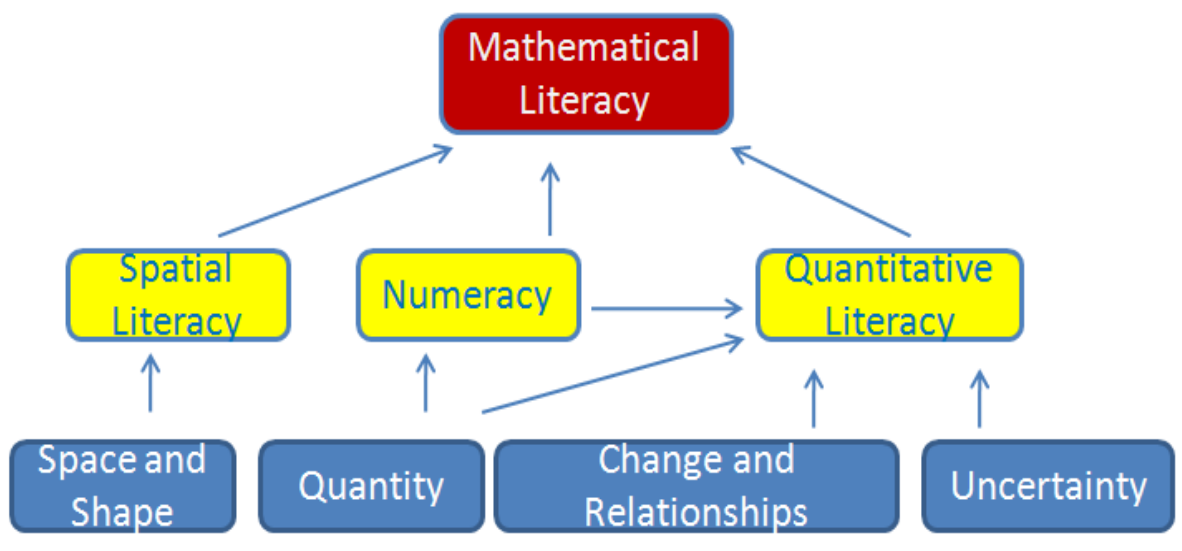

Gambar 2. Struktur Literasi Matematika menurut De'Lange

Literasi spasial memberdayakan individu untuk memahami dunia tiga dimensi di mana ia tinggal dan bergerak. Hal ini membutuhkan pemahaman tentang sifat benda, posisi relatif objek dan pengaruhnya terhadap persepsi visual seseorang, penciptaan semua jenis jalur tiga-dimensi dan rute, praktek navigasi, dll. Berhitung adalah kemampuan untuk menangani angka dan data dalam rangka untuk mengevaluasi pernyataan tentang masalah dan situasi yang memerlukan mental yang memproses dan memperkirakan konteks dunia nyata. Literasi kuantitatif memperluas berhitung untuk memasukkan penggunaan matematika dalam menghadapi perubahan, hubungan kuantitatif dan ketidakpastian.

Matematika berhubungan dengan masalah "real". Hal ini berarti bahwa masalah tersebut biasanya muncul pada sebuah situasi. Sebagai kesimpulan, siswa harus mampu menyelesaikan masalah nyata (real world problem) yang mensyaratkan mereka untuk menggunakan kemampuan dan kompetensi yang telah mereka peroleh melalui pengalaman di sekolah dan sehari-hari. Proses yang mendasar dari hal ini adalah "matematisasi". Proses ini membawa siswa berubah dari masalah konteks dari dunia nyata ke dunia matematika yang dibutuhkan untuk memecahkan masalah tersebut. Matematisasi membawa siswa dalam menginterpretasi dan mengevaluasi masalah serta merefleksi solusinya untuk meyakinkan bahwa solusi yang telah ditemukan sesuai dengan situasi real yang menimbulkan masalah tersebut.

OECD sebagai penyelenggara PISA fokus pada sejumlah pengetahuan matematika anak berumur 15 tahun yang mampu digunakan dalam berbagai macam konteks dan situasi. Masalah yang diberikan biasanya membutuhkan pendekatan-pendekatan reflektif dan kreativitas. Oleh karena itu, 
PISA menekankan pada kemampuan dan pengetahuan matematika yang diluar dari matematika yang telah didefinisikan dan terbatas pada kurikulum sekolah.

Kurikulum 2013 lebih menekankan kepada kompetensi inti mata pelajaran. Kompetensi inti menjadi unsur pengorganisasi kompetensi dasar, dimana semua kompetensi dasar dan proses pembelajaran dikembangkan untuk mencapai kompetensi dasar yang dinyatakan dalam kompetensi inti. Berdasarkan Permendikbud No. 69 tahun 2013 tentang "Kurikulum SMA maupun MA" menyatakan bahwa:

Kompetensi Inti untuk pengetahuan untuk matematika meliputi memahami, menerapkan, dan menganalisis pengetahuan faktual, konseptual, prosedural, dan metakognitif berdasarkan rasa ingin tahunya tentang ilmu pengetahuan, teknologi, seni, budaya, dan humaniora dengan wawasan kemanusiaan, kebangsaan, kenegaraan, dan peradaban terkait penyebab fenomena dan kejadian, serta menerapkan pengetahuan prosedural pada bidang kajian yang spesifik sesuai dengan bakat dan minatnya untuk memecahkan masalah.

Untuk penilaian dalam Permendikbud No. 66 tahun 2013 tentang "Standar Penilaian" menyatakan bahwa "Cakupan penilaian merujuk pada ruang lingkup materi, kompetensi mata pelajaran/kompetensi muatan/kompetensi program, dan proses dengan menggunakan penilaian berbasis portofolio". Dengan penilaian berbasis portofolio, tugas-tugas yang dibebankan kepada siswa bukan hanya sekedar menyelesaikan soal-soal dan latihan saja, tetapi lebih dari itu. Sebaiknya peserta didik diberikan tugas-tugas yang dapat menumbuhkan pemahaman konseptual dan pengembangan keterampilan dan kebiasaan berpikir.

Berdasarkan hal tersebut diatas, maka penting adanya literasi matematika dalam pengajaran matematika. Departemen Instruksional Publik (DPI) Wisconsin menyatakan dalam situsnya bahwa untuk mengajarkan literasi matematika, dalam kurikulum dan pengajaran sebaiknya harus menyertakan: a) konsep-konsep matematika yang relevan, prinsipal dan procedural, b) konteks kehidupan yang dapat diselidiki dan dimodelkan secara matematis, c) kaya akan tugas-tugas matematika yang menumbuhkan pemahaman konseptual dan pengembangan keterampilan dan kebiasaan berpikir.

\section{KESIMPULAN}

Berdasarkan pembahasan yang telah diuraikan diatas, maka disimpulkan beberapa hal yaitu:

1. Kurikulum tahun 2013 merupakan tinjauan terhadap kurikulum sebelumnya yang tujuannya adalah untuk memperbaiki Standar Kompetensi dan Kompetensi Dasar yang tidak relevan bagi siswa, perbaikan terhadap sistem pelatihan guru, serta penggunaan alat dan teknologi dalam implementasi pembelajaran matematika di sekolah.

2. Kurikulum matematika mengacu pada Standar Kompetensi Lulusan (SKL) yang diuraikan dalam Kompetensi Inti dan Kompetensi Dasar dengan mengacu pada materi isi. Ada empat aspek dalam Kompetensi Inti untuk matematika, yaitu kompetensi inti untuk sikap spiritual, kompetensi inti untuk sikap sosial, kompetensi inti pengetahuan dan kompetensi inti keterampilan.

3. Untuk mencapai tujuan pendidikan yang mengacu kepada Standar Kompetensi Lulusan (SKL), Kompetensi Inti, dan Kompetensi dasar matematika, serta mengacu pada Standar Penilaian, diperlukan literasi matematika dalam proses pembelajaran matematika. Dengan literasi 
matematika, siswa akan mampu melakukan, memahami, dan menerapkan matematika, tidak hanya di dalam kelas tetapi juga dalam kehidupan sehari-hari, selain itu siswa diajak untuk berpikir kritis terhadap instruksi yang diberikan.

\section{DAFTAR PUSTAKA}

Ronda, Erlina. 2011. What is Mathematical Literacy, (online), (http: //math4teaching.com/2010/03/12/what-is-mathematical-literacy. Diakses 28 Agustus 2013)

Department of Public Inctruction. 2012. Disciplinary Literacy in Mathematics, (online), (https://sites.google.com/a/dpi.wi.gov/disciplinary-literacy-in-mathematics. diakses 28 Agustus 2013).

Hasan, Hamid. 2013. Informasi Kurikulum 2013, (online), (http://upi.edu/main/file/Slide 1 Informasi Kurikulum 2013 - Prof. Dr. H. S. Hamid Hasan MA.pdf. diakses 28 Agustus 2013).

Hudson, David, L. (2007). Educational Standard; Point-Counterpoint. New York: Infobase Publishing.

Jacobs, Heidi Hayes. (2010). Curriculum 21; Essential Education for Changing World. Alexandia: ASCD Publication.

Kementerian Pendidikan dan Kebudayaan. 2013. Implementasi Kurikulum 2013, (online), (http://www.slideshare.net/nayantakahusnahartono/sosialisasi-implementasi-kurikulum2013.html. Diakses 28 Agustus 2013).

Kementerian Pendidikan dan Kebudayaan. 2013. Pengembangan Kurikulum 2013: Paparan Menteri Pendidikan dan Kebudayaan RI, (online), (http://upi.edu/main/file/Paparan Mendikbud Sosialisasi Kurikulum 2013 Bandung 16 Maret 2013 Tayang.pptx. Diakses 28 Agustus 2013).

Organisation for Economic Co-operation and Development. (2009). Learning Mathematics for Life: A View Perpective from PISA. Paris: OECD Publications.

Peraturan Menteri Pendidikan dan Kebudayaan Republik Indonesia Nomor 54 tahun 2013 tentang Standar Kompetensi Lulusan Pendidikan Dasar dan Menengah. 2013.

Peraturan Menteri Pendidikan dan Kebudayaan Republik Indonesia Nomor 65 tahun 2013 tentang Standar Proses Pendidikan Dasar dan Menengah. 2013.

Peraturan Menteri Pendidikan dan Kebudayaan Republik Indonesia Nomor 66 tahun 2013 tentang Standar Penilaian Pendidikan. 2013.

Peraturan Menteri Pendidikan dan Kebudayaan Republik Indonesia Nomor 69 tahun 2013 tentang Kerangka Dasar dan Struktur Kurikulum Sekolah Menengah Atas/Madrasah Aliyah. 2013.

Tim BSNP. 2013. Paradigma Pendidikan Nasional Abad XXI (bagian VII). Buletin BSNP Media Komunikasi dan Dialog Standar Pendidikan, Vol. VIII/No. 1/Maret 2013: 3-8.

UNESCO. (2011). UNESCO and Education; Everyone Has the Right to Education. Columbia: UNESCO. 